\title{
European Indicators of Social Quality Network List
}

The articles in this European Journal of Social Quality have resulted from a European Network Project on Indicators of Social Quality, carried out between 2001 and 2005 and supported by the Fifth Framework Programme by DG Research of the European Commission and the Netherlands Organisation for Scientific Research (NWO). The network was coordinated by the European Foundation on Social Quality. The full national reports, on which these articles are based, as well as the Final Report of this project by Dr. Laurent van der Maesen, Prof. Alan Walker and Drs Margo Keizer, can be downloaded from www.socialquality.eu

\section{The participants of the European Network on Indicators of Social} Quality:

- Prof. Alan Walker (chair), Sheffield University, UK

- Dr Laurent van der Maesen (co-ordinator), European Foundation on Social Quality, the Netherlands

- Prof. Bea Cantillon, University of Antwerp, Belgium

- Prof. Denis Bouget, Maison des Sciences de l'Homme Ange Guépin, France

- Dr Mika Gissler, STAKES, Finland

- Prof. Ilona Ostner and Prof. Steffen Kühnel, Georg-August University of Göttingen, Germany

- Prof. Maria Petmesidou, Democritus University of Thrace, Greece

- Dr Erzsébet Bukodi, Hungarian Central Statistical Office, Hungary

- Prof. Séamus O'Cinnéide, National University of Ireland, Ireland

- Prof. Chiara Saraceno, University of Turin, Italy

- Prof. Chris de Neubourg, University of Maastricht, the Netherlands

- Dr Heloísa Perista, CESIS, Portugal

- Dr Srna Mandic, University of Ljubljana, Slovenia

- Prof. Juan Monreal, University of Murcia, Spain

- Prof. Göran Therborn, SCASSS, Sweden

- Dr David Phillips, Sheffield University, UK

- Fintan Farrell, European Anti-Poverty Network, Belgium

- Marjaliisa Kauppinen, International Council on Social Welfare, Finland

The International Advisors

- Dr Wolfgang Beck, the Netherlands

- Dr Yitzhak Berman, European Centre for Social Welfare, Policy and Research, Austria 
- Prof. Dave Gordon, University of Bristol, Townsend Centre for International Poverty Research, UK

- Dr Peter Herrmann, ESOSC, Ireland

\section{The scientific assistants of the network:}

- Veerle De Maesschalck, Centre for Social Policy (UFSIA) Antwerp, Brussels, Belgium

- Barbara Demeyer, European Anti-Poverty Network, Brussels, Belgium

- Mika Vuori, STAKES, Helsinki, Finland

- Aki Siltaniemi, International Council on Social Welfare (ICSW), Helsinki, Finland

- Frederic Salladarré and Mourad Sandi, Maison des Sciences de l'Homme Ange Guépin, Nantes, France

- Michael Ebert, University of Göttingen, Institut für Sozialpolitik, Germany

- Periklis Polyzoidis, Democritus University, Dept. of Sociological Administration, Komotini, Greece

- Szilvia Altorjai, Hungarian Central Statistical Office, Budapest, Hungary

- Jean Cushen and Fearghas 'O Gabhan, University of Ireland, Centre for Applied Social Studies, Kildaere, Ireland

- Ester Cois and Susanna Terracina, University of Turin, Dep. of Social Sciences, Italy

- Pia Steffens, University of Maastricht, Faculty of Economic Science, the Netherlands

- Pedro Perista, CESIS, Lisbon, Portugal

- Ruzica Boskic and Masa Filipovic, University of Ljubljana, Faculty of Social Sciences, Slovenia

- Salvadora Titos, University of Murcia, Dept. of Sociology \& Economic Studies, Spain

- Sonia Therborn, SCASS, Uppsala, Sweden

- Andrea Wigfield and Sue Hacking, University of Sheffield, Department of Sociological Studies, UK 